\title{
SEVENTH ANNUAL LIST OF PAPERS
}

\section{READ BEFORE THE AMERICAN MATHEMATICAL SOCIETY AND SUBSEQUENTLY PUBLISHED, INCLUDING REFERENCES TO THE PLACES OF THEIR PUBLICATION.}

BLAKE, E. M. Note upon a Representation in Space of Ellipses drawn by an Ellipsograph. Read (Chicago) April 24, 1897. Annals of Mathematics, Vol. 11, No. 6, pp. 195-196; Oct., 1897.

Bôcher, M. The Roots of Polynomials which Satisfy Certain Linear Differential Equations of the Second Order. Read Dec. 29, 1897. Bulletin of the American Mathematical Society, vol. 4, No. 6, pp. 256258; March, 1898.

- The Theorems of Oscillation of Sturm and Klein (First Paper). Read Dec. 29, 1897. Bulletin of the American Mathematical Society, vol. 4, No. 7, pp. 295-313; A pril, 1898.

- The Theorems of Oscillation of Sturm and Klein (Second Paper). Read Feb. 26, 1898. Bulletin of the American Mathematical Society, vol. 4, No. 8, pp. 365-376 ; May, 1898.

- Note on Poisson's Integral. Read April 30, 1898. Bulletin of the American Mathematical Society, vol. 4, No. 9, pp. 424-426; June, 1898.

Bolza, O. Concerning the Cubic Involution and the Cubic Transformation of Elliptic Functions. Read Aug. 16, 1897 and (Chicago) Dec. 30, 1897. Mathematische Annalen, vol. 50, No. 1, pp. 68-102; Dec., 1897.

Bouton, C. L. Some Examples of Differential Invariants. Read Dec. 29, 1897. Bulletin of the American Mathematical Society, vol. 4, No. 7, pp. 313-322 ; April, 1898.

Brown, E. W. Note on the Steering of an Eight-oared Boat. Read Oct. 30, 1897. Bulletin of the American Mathematical Society, vol. 4, No. 2, pp. 77-78; Nov., 1897.

Chessin, A. S. Note on Hyperelliptic Integrals. Read Oct. 30, 1897. Bulletin of the American Mathematical Society, vol. 4, No. 3, pp. 9396 ; Dec., 1897.

Dickson, L. E. Orthogonal Group in a Galois Field. Read Dec. 29, 1897. Bulletin of the American Mathematical Society, vol. 4, No. 5, pp. 196-200 ; Feb., 1898.

- Systems of Simple Groups Derived from the Orthogonal Group. Read (Chicago) Dec. 30, 1897. Bulletin of the American Mathematical Society, vol. 4, No. 8, pp. 382-389; May, 1898. Proceedings of the California Academy of Sciences, vol. 1, No. 4, pp. 29-46; March, 1898.

- The St ucture of the Hypoabelian Groups. Read (Chicago) April 9, 1898. Bulletin of the American Mathematical Society, vol. 4, No. 10, pp. 495-510; July, 1898.

Engbera, C. C. On the Triple Focus of a Cartesian. Read (Chicago) Dec. 31, 1898. Annals of Mathematics, vol. 12 , No. 2, pp. 54-56; May, 1898. 
HathawAy, A. S. Quaternions as Numbers of Four-Dimensional Space. Read (Chicago) April 24, 1897. Bulletin of the American Mathematical Socrety, vol 4, No. 2, pp. 54-57 ; Nov., 1897.

HAwKes, H. E. Limitations of Greek Arithmetic. Read April 30, 1898. Bulletin of the American Mathematical Society, vol. 4, No. 10, pp. 530$535 ; \mathrm{July}, 1898$.

HILL, G. W. On Intermediary Orbits in the Lunar Theory. Read Oct. 30, 1897. Astronomical Journal, vol. 18, No. 11, pp. 81-87 ; Nov., 1897.

Hill, J. E. On Three Septic Surfaces. Read Aug. 31, 1896. American Journal of Mathematics, vol. 19, No. 4, pp. 289-311; Oct., 1897.

Holgate, T. F. A Geometrical Locus Connected with a System of Coaxial Circles. Read Aug. 16, 1897. Bulletin of the American Mathematical Society, vol. 4, No. 2, pp. 63-67 ; Nov., 1897.

Hutchinson, J. I. On the Reduction of Hyperelliptic Functions $(p=2)$ to Elliptic Functions by a Transformation of the Second Degree. Read Aug. 16, 1897. Doctor Dissertation, University of Chicago, 1897, pp. 40.

- Note on the Tetrahedroid. Read Feb. 26, 1898. Bulletin of the American Mathematical Society, vol. 4, No. 7, pp. 327-329 ; April, 1898.

LovetT, E. O. Note on the Invariants of $n$ Points. Read April 24, 1897. Bulletin of the American Mathematical Society, vol. 4, No. 2, pp. 58-59 ; Nov., 1897.

- Certain Classes of Point Transformations in the Plane. Read May 29, 1897. Bulletin of the American Mathematical Society, vol. 4, No. 3, pp. 97-107; Dec., 1897.

- Note on the Fundamental Theorems of Lie's Theory of Continuous Groups. Read Oct. 30, 1897. Bulletin of the American Mathematical Society, vol. 4, No. 2, pp. 59-63 ; Nov., 1897.

- Certain Invariants of a Quadrangle by Projective Transformation. Read Dec. 29, 1897. Annals of Mathematics, vol. 12, No. 3, pp. 7986 ; June, 1898.

- Point Transformations in Elliptic Coördinates of Circles having Double Contact with a Conic. Read Dec. 29, 1897. American Journal of Mathematics, vol. 20, No. 3, pp. 242-244; July, 1898.

- Note on the Infinitesmal Projective Transformation. Read April 30, 1898. Bulletin of the American Mathematical Society, vol. 4, No. 10, pp. 515-519; July, 1898.

- Infinitesimal Transformations of Concentric Conics. Read April 30, 1898. Bulletin of the American Mathematical Society, vol. 4, No. 10, pp. 520-524; July, 1898.

McClintock, E. Further Researches in the Theory of Quintic Equations. Read Aug. 17, 1897. American Journal of Mathematics, vol. 20, No. 2, pp. 157-192 ; April, 1898.

Merriman, M. The Probability of Hit when the Probable Error in Aim is Known; With a Comparison of the Probabilities of Hit by the Methods of Independent and Parallel Fire from Mortar Batteries, Read Oct. 30, 1897. Journal of the U. S. Artillery, vol. 8, No. 2, pp. 129-141 ; Sept.-Oct., 1897. 
Miller, G. A. On the Commutator Groups. Read Ang. 17, 1897. Bulletin of the American Mathematical Society, vol. 4, No. 4, pp. 135139 ; Jan., 1898.

On the Limit of Transitivity of the Multiply Transitive Substitution Groups That do not Contain the Alternating Group. Read Dec. 29, 1897. Bulletin of the American Mathematical Society, vol. 4, No. 4, pp. 140-143; Jan., 1898.

- On the Perfect Groups. Read (Chicago) Dec. 30, 1897. American Journal of Mathematics, vol. 20, No. 3, pp. 277-282 ; July, 1898

- On an Extension of Sylow's Theorem. Read Feb. 26, 1898. $B$ ulletin of the American Mathematical Society, vol. 4, No. 7, pp. 323-327; April, 1898.

- On the Hamilton Groups. Read April 30, 1898. Bulletin of the American Mathematical Society, vol. 4, No. 10, pp. 510-515 ; July, 1898. On the Supposed Five-fold Transitive Function of 24 Elements and $19 ! \div 48$ Values. Read April 30, 1898. Messenger of Mathematics, vol. 27, No. 12, pp. 187-190; April, 1898.

Moone, E. H. Concerning the Abstract Groups of Order $k$ ! and $\frac{1}{2} k$ ! Holohedrically Isomorphic with the Symmetric and the Alternating Substitution Groups on $k$ Letters. Read (Chicago) Jan. 1, 1897. Proceedings of the London Mathematical Society, vol. 28, No. 597, pp. 357-366 ; Dec., 1896.

- Concerning Regular Triple Systems. Read Aug. 17, 1897. Bulletin of the American Mathematical Society, vol. 4, No. 1, pp. 11-16 ; Oct., 1897.

MonLey, F. A Construction by the Ruler of a Point Covariant With Five Given Points. Read Dec. 30, 1896. Mathematische Annalen, vol. 49, Nos. 3-4, pp. 596-600.

- A Generating Function for the Number of Permutations with an Assigned Number of Sequences. Read May 29, 1897. Bulletin of the American Mathematical Society, vol. 4, No. 1, pp. 23-28 ; Oct., 1897.

Newcomв, S. The Philosophy of Hyperspace. [Presidential Address.] Read Dec. 29, 1897. Bulletin of the American Mathematical Society, vol. 4, No. 5, pp. 187-195 ; Feb., 1898. Science, vol. 7. No. 158, pp. 1-7 ; Jan. 7, 1898.

Newson, H. B. Continuous Groups of Circular Transformations. Read April 24, 1897. Bulletin of the American Mathematical Society, vol. 4, No. 3, pp. 107-121 ; Dec., 1897.

- On Hessians, and Steinerians of Higher Orders in Geometry of One Dimension. Read (Chicago) April 24, 1897. Annals of Mathematics, vol. 11, Nos. 3-4, pp. 121-128 ; Feb.-A pril, 1897.

- Normal Forms of Projective Transformations. Read (Chicago) Dec. 30, 1897. Kansas University Quarterly, vol. 7, No. 3, pp. 125141 ; July, 1898.

Osgood, W. F. Example of a Single-Valued Function with a Natural Boundary, whose Inverse is also Single-Valued. Read A pril 30, 1898. Bulletin of the American Mathematical Society, vol. 4, No. 9, pp. 417424 ; June, 1898.

Pinrpont (J.). Early History of Galois' Theory of Equations. Read Feb. 26, 1898. Bulletin of the American Mathematical Society, vol. 4, No. 7, pp. 332-340; April, 1898. 
Porter, M. B. Note on the Roots of Bessel's Functions. Read Feb. 26, 1898. Bulletin of the American Mathematical Society, vol. 4, No. 6, pp. 274-275 ; March, 1898.

RoE, E. D. Note on the Integral and Integro-Geometric Series. Read Sept. 1, 1896. Annals of Mathematics, vol. 11, No. 6, pp. 184-194; Oct., 1897.

SAUREL, P. L. Note on Integrating Factors. Read Feb. 26, 1898 Bulletin of the American Mathematical Society, vol. 4, No. 7, pp. 329331 ; April, 1898.

Scotr, C. A. Studies in the Transformation of Plane Curves. Read April 25, 1896. Quarterly Journal of Marthematics, vol. 29, No. 116, pp. 329-381 ; March, 1898.

- Note on Linear Systems of Curves. Read Oct. 30, 1897. Nieuw Archief voor Wiskunde, 2d Series, vol. 3.

SNyder, V. Geometry of Some Differential Expressions in Hexaspherical Coördinates. Read Aug. 16,1897. Bulletin of the American Mathematical Society, vol. 4, No. 4, pp. 144-154 ; Jan., 1898.

StaRKWEather, G. P. A Solution of the Biquadratic by Binomial Resolvents. Read April 30,1898. Bulletin of the American Mathematical Society, vol. 4, No. 10, pp. 524-528; July, 1898.

STrong, W. M. Is Continuity of Space Necessary to Euclid's Geometry? Read April 30, 1898. Bulletin of the A merican Mathematical Society, vol. 4, No. 9, pp. 443-448; June, 1898.

VAN VLECK, E. B. On the Polynomials of Stieltjes. Read April 30 , 1898. Bulletin of the American Mathematical Society, vol. 4, No. 9, pp. 426-438; June, 1898.

Webster, A. G. Note on Stokes's Theorem in Curvilinear Coördinates. Read April 30, 1898. Bulletin of the American Mathematical Society, vol. 4, No. 9, pp. 438-441; June, 1898.

Whittemore, J. K. A Proof of the Theorem : $\frac{\partial^{2} f}{\partial x \partial y}=\frac{\partial^{2} f}{\partial y \partial x}$. Read April 30, 1898. Bulletin of the American Mathematical Society, vol. 4, No. 8, pp. 389-390; May, 1898.

White, H. E. The Construction of Special Regular Reticulations on a Closed Surface. Read in part (Chicago) Jan. 1, 1897, and in final form April 30, 1898. Bulletin of the American Mathematical Society, vol. 4, No. 8, pp. 376-382; May, 1898.

Collineations in a Plane with Invariant Quadric or Cubic Curves* Read Aug. 17, 1897. Bulletin of the American Mathematical Society' vol. 4, No. 1, pp. 17-23 ; Oct., 1897.

- Inflexional Lines, Triplets, and Triangles Associated with the Plane Cubic Curve. Read Feb. 26, 1898. Bulletin of the American Mathematical Society, vol. 4, No. 6, pp. 258-260 ; March, 1898. 